\title{
IMPLEMENTASI KEBIJAKAN BELA NEGARA UNTUK MEWUJUDKAN KETAHANAN NASIONAL DI WILAYAH KOMANDO DISTRIK MILITER 1309 / MANADO
}

\section{IMPLEMENTATION OF STATE DEFENSE POLICIES TO REALIZE NATIONAL RESILIENCE IN THE 1309 MILITARY DISTRICT COMMAND / MANADO REGION}

\author{
Rudolf Toar Shaloom Manoppo ${ }^{(1)}$, Agustinus Pati ${ }^{(2)}$, Alfon Kimbal ${ }^{(2)}$ \\ ${ }^{1)}$ Staf Ahli bidang Taktik \& Strategi, Sekolah Staf dan Komando TNI AD (SESKOAD) \\ ${ }^{2)}$ Staf Pengajar dan Peneliti pada Program Studi Pengelolaan Sumberdaya Pembangunan, Pascasarjana Universitas Sam Ratulangi, Manado \\ *Penulis untuk korespondensi: dandiminhil@gmail.com / anshabeljoy@ gmail.com :
}

\begin{tabular}{ll}
\hline Naskah diterima melalui Email Jurnal Ilmiah agrisosioekonomi@unsrat.ac.id & : Senin, 11 Januari 2021 \\
Disetujui diterbitkan & : Jumat, 22 Januari 2021 \\
\hline
\end{tabular}

\begin{abstract}
This study aims to analyze the implementation of State Defense policies to achieve National Resilience. This research was conducted in the area of Kodim 1309 which was carried out by the Regional Command Unit (Satkowil) namely Kodim 1309 / Manado Korem 131 / Stg Kodam XIII / Mdk in the city of Manado and its surroundings. This research was conducted from December 2019 to February 2020. This study used primary and secondary data. Primary data were obtained by observation and interview methods, while secondary data were collected using documents related to the topic of this research, particularly with regard to land defense. Interviews were conducted with 15 informants who were selected purposively. Data analysis used qualitative data analysis techniques. The results showed that, first, the communication process carried out by Kodim 1309 as the executor was carried out by building communication with stakeholders in the Kodim 1309 area, which process went well and was accepted by stakeholders and the general public. Second, the implementation of the institutional strategy of the bureaucratic structure carried out by Kodim 1309 / Manado to the Koramil in its ranks has been good through forms of supervision. Third, in the aspect of resources in implementing the national defense of the Police, Kodam 1309 uses human resources, namely army personnel and available facilities. These activities have not been maximized because there are not enough personnel so that to carry out state defense activities was limited of number and face various other activities that must also be carried out too. Fourth, the attitude of policy implementers has not shown maximum results and has not been running sustainably.
\end{abstract}

Keywords: policy, state defense, national resiliencs, Indonesian National Army (TNI)

\section{ABSTRAK}

Penelitian ini bertujuan untuk menganalisis implementasi kebijakan Bela Negara untuk mencapai Ketahanan Nasional. Penelitian ini dilakukan di areal Kodim 1309 yang dilaksanakan oleh Satuan Komando Daerah (Satkowil) yaitu Kodim 1309 / Manado Korem 131 / Stg Kodam XIII / Mdk meliputi wilayah Kota Manado dan sekitarnya. Penelitian ini dilaksanakan pada bulan Desember 2019 sampai Februari 2020, menggunakan data primer dan sekunder. Data primer dikumpulkan dengan metode observasi dan wawancara sedangkan data sekunder diperoleh dari dokumen-dokumen yang berkaitan dengan topik penelitian ini, khususnya yang berkaitan dengan pertahanan darat. Wawancara dilakukan pada 15 orang informan yang dipilih secara sengaja. Analisis data menggunakan teknik analisis data kualitatif. Hasil penelitian menunjukkan bahwa, pertama, proses komunikasi yang dilakukan oleh Kodim 1309 sebagai pelaksana kebijakan dilakukan dengan membangun komunikasi dengan para pemangku kepentingan (stakeholders) di wilayah Kodim 1309 dimana prosesnya berjalan baik dan diterima oleh para stakeholders serta masyarakat luas. Kedua, implementasi strategi kelembagaan struktur birokrasi yang dilakukan oleh Kodim 1309 / Manado terhadap Koramil di jajarannya sudah baik dalam bentuk pengawasan. Ketiga, pada aspek sumber daya dalam penyelenggaraan pertahanan negara Polri, Kodam 1309 menggunakan sumber daya manusia yaitu personel TNI dan fasilitas yang tersedia. Kegiatan tersebut belum maksimal karena jumlah personelnya yang belum sesuai dengan jumlah ideal sehingga untuk melaksanakan kegiatan bela negara pun terkendala karena menghadapi berbagai kegiatan lain yang juga harus dilakukan. Keempat, sikap pelaksana kebijakan belum menunjukkan hasil yang maksimal dan belum berjalan secara berkelanjutan.

Kata kunci: kebijakan, bela negara, ketahanan nasional, Tentara Nasional Indonesia (TNI) 


\section{PENDAHULUAN}

\section{Latar Belakang}

Indonesia merupakan negara kepulauan terbesar di dunia memiliki posisi geografis yang terletak antara 2 benua yakni Benua Asia dan benua Australia juga diapit oleh 2 samudera besar yaitu Samudera Hindia dan Samudera pasifik. Dari sudut pandang geopolitik, bentangan tersebut menjadikan Indonesia negara yang memiliki kekuatan dan posisi yang strategis dalam peraturan dan hubungan antar bangsa dalam lingkup kawasan global. Hal tersebut berdasarkan pemikiran bahwa ruang/wilayah merupakan inti dari geo politik, karena disitu juga adalah tempat segala dinamika dalam dunia politik dan militer. Penguasaan wilayah secara de facto dan de jure adalah legitimasi dari kekuasaan politik. Dengan bertambahnya ruang negara ataupun berkurang yang disebabkan berbagai hal, erat kaitannya dengan kedudukan dan kehormatan dan kedaulatan Bangsa dan Negara tersebut. (https://www.kemhan.go.id/belanegara/opini/asd).

Dalam tataran dunia internasional, setiap negara berlomba-lomba untuk menunjukkan diri paling berkuasa atau paling dominan, sejak perang dunia kedua berakhir, perang menggunakan armada militer semakin berkurang, diganti dengan persaingan antar negara menjadi yang terbaik dan mendominasi dunia. Indonesia secara garis besar memiliki potensi yang luar biasa untuk menjadi negara yang berpengaruh didunia terlihat dari posisi strategis Indonesia sehingga Indonesia memiliki posisi tawar yang tinggi di dunia internasional selain itu juga ditunjang dengan potensi sumberdaya alam yang kaya dibandingkan dengan negara lainya. Namun dengan kekayaan yang dimiliki Indonesia tersebut menjadikan Indonesia 'sasaran' negara lain untuk 'dikuasai' dan dimanfaatkan. Oleh sebab itu ancaman semacam itu harus disadari bukan hanya Pemerintah dan Tentara Nasional Indonesia, namun juga wajib di sadari dan diantisipasi oleh segenap elemen bangsa baik yang tua sampai yang muda. Kesadaran akan potensi ruang yang dimiliki Indonesia merupakan tanggungjawab semua dengan bersatu padu sesuai dengan potensi dan kemampuan menghadapi ancaman kekinian tersebut.

Pengaruh dan dampak negatif dari perkembangan lingkungan strategis yang juga disertai dengan berubahnya persepsi dan hakekat ancaman terhadap eksistensi dan kedaulatan Bangsa Indonesia tentu wajib dicermati dan disikapi oleh Bangsa Indonesia dengan serius. Hal tersebut menjadi penting mengingat akan perkembangan dan kemajuan ilmu pengetahuan dan teknologi sekarang ini yang juga telah berdampak dengan semakin berkembangnya peperangan modern dalam bentuk
Asymmetric Warfare dan proxy war. Oleh sebab itu salah satu upaya yang wajib menjadi fokus segenap elemen bangsa adalah kemandirian dan penguasaan, pengembangan serta pemanfaatan teknologi dalam berbagai bidang. Pada konteks Ketahanan dan Pertahanan Nasional, maka pengusasaan ilmu pengetahuan dan teknologi tersebut merupakan cara cerdas untuk mengantisipasi setiap ancaman yang datang baik ancaman Militer maupun Nir Militer.

Ketahanan Nasional adalah dasar landasan konsepsi strategis yang juga merupakan instrumen yang bertujuan menganalisis dalam memecahkan berbagai permasalahan bangsa. Ketahanan Nasional pula mempunyai hakekat dan arti kondisi sekaligus konsepsi pembangunan nasional dan mencapai tujuan serta cita- cita Bangsa Indonesia. Sebagai suatu kondisi Ketahanan Nasional adalah kondisi dinamis bangsa yang mengandung ketangguhan serta keuletan dan juga kemampuan Bangsa Indonesia untuk mengembangkan Kekuatan Nasional dalam menghadapi berbagai macam ancaman dalam bentuk apapun baik yang datang dari dalam maupun ancaman yang datang dari luar. Sebagai kondisi, Ketahanan Nasional juga merupakan kondisi kehidupan nasional yang yang diaplikasikan dan dibina sejak sekarang dan secara berkelanjutan, terpadu dan juga sinergi.

Kehidupan Nasional berjalan secara dinamis namun kontra produktif untuk penguatan Wawasan Kebangsaan. Dampak dari demokratisasi tidak didasari dengan pemahaman nilai Pancasila, telah menimbulkan sikap individualistis yang jauh dengan nilai-nilai yang terkandung dalam Pancasila yang lebih mengedepankan semangat gotong royong, kerjasama, kesamaan, keseimbangan, serta kesederajatan antar manusia satu dengan manusia yang lain. Perubahan-perubahan tata nilai serta tata laku tersebut tercermin dari berbagai sikap yang pragmatis dalam menyikapi dan menyelesaikan berbagai permasalahan Bangsa Indonesia.

Saat ini dengan banyaknya perkembangan dalam dunia teknologi dan sains nampak bahwa Pancasila yang merupakan dasar negara Indonesia cenderung hanya dipandang sebagai simbol yang mulai kehilangan roh serta makna filosofisnya. Jadi tidak mengherankan jika saat ini Nasionalisme atau Wawasan Kebangsaan Indonesia menjadi barang yang mewah yang sudah sangat sulit untuk ditemukan dikalangan generasi muda. Wawasan Kebangsaan bukanlah topik menarik yang dibahas dikalangan anak muda sekarang ini, kebanyakan mereka lebih suka membahas perkembangan tren busana, artis dan perkembangan teknologi bangsa lain. Pertanyaannya sekarang, apakah sekarang Indonesia mengalami krisis Wawasan Kebangsaan atau hanya sekedar euphoria semata. 
Wawasan Kebangsaan sekarang ini terlihat hanya sebuah abstrak yang tidak bisa disentuh serta mengalami pendangkalan makna yang mendasar. Perkembangan globalisasi yang masuk kedalam batas-batas negara menyebabkan pengaburan persepsi dari Wawasan Kebangsaan Indonesia yang sebenarnya adalah hal yang esensi dalam mempertahankan eksistensi serta kedaulatan Bangsa Indonesia. Wujud ancaman yang berkembang pada dewasa ini bukanlah ancaman yang bersifat fisik lagi, pergerakan kekuatan militer bukan lagi menjadi pilihan kebanyakan negara-negara yang memiliki kepentingan pada negara lain. Ideologi, ekonomi, budaya dan politik yang saat ini menjadi pilihan negara lain untuk menaklukan negara lain. Meskipun tidak nampak secara fisik, namun dampak yang ditimbulkan akan sangat terasa bukan hanya pada tingkat kota namun akan sangat terasa sampai pada tingkat desa-desa.

Dalam rangka menghadapi berbagai ancaman tersebut, negara bukan tidak hanya menjadi elemen tunggal yang harus mengemban tanggungjawab dalam menjauhkan ancaman-ancaman yang datang namun partisipasi dan juga peran aktif dari semua elemen bangsa serta warga negara akan mampu menentukan keberhasilan menghadapi dan mengantisipasi ancaman yang hendak ditimbulkan. Untuk itulah generasi muda sekarang ini harus mampu menyadari bahwa sebagai elemen bangsa dengan kekuatan Nir Militer yakni dengan kemampuan intelektual yang baik, generasi intelektual muda memiliki peran yang sangat penting dalam menghadapai ancaman Nir Militer tersebut dengan berbagai keahlian dan kompetensi yang dimiliki. Dengan kondisi tersebut dibutuhkan kehadiran generasi muda yang memiliki intelektual yang tinggi serta berkarakter yang juga wajib memiliki jiwa Nasionalisme Kebangsaan yang kuat.

Kekuatan serta ketangguhan yang dimiliki Bangsa Indonesia dalam mempertahankan kedaulatan bangsa merupakan sebuah kekuatan pertahanan diri yang solid dan sulit di tembus yang dibangun atas dasar Nasionalisme dan dasar nilai kebangsaan serta jiwa Bela Negara. Bela Negara serta jiwa Nasionalisme bukan hanya sekedar retorika dalam kehidupan berbangsa dan bernegara, tapi juga harus mampu diaplikasikan serta diwujudkan dalam kehidupan nyata oleh semua elemen bangsa terutama kalangan generasi muda. Kecerdasan intelektual yang adalah potensi besar yang dimiliki oleh generasi muda harus mampu dikembangkan dengan baik namun harus juga diseimbangkan dengan kecerdasan emosional, moral dan spiritual. Keseimbangan tersebut sangat dibutuhkan sebagai bentuk rangkaian membangun kesadaran individu yang berkaitan dengan Bela Negara. Hal tersebut yang sesungguhnya wajib disadari oleh kalangan generasi muda agar dipahami dan juga dikerjakan untuk memenuhi hak serta kewajiban Bela Negara dalam sudut pandang Ketahanan Nasional.

Kesadaran akan Bela Negara diamanatkan dalam Undang Undang Dasar Negara Republik Indonesia dalam pasal 27 ayat 3 yang berbunyi 'setiap warga Negara berhak dan wajib ikut serta dalam upaya pembelaan Negara,' yang selanjutnya diperkuat dalam pasal 30 ayat 1 yang berbunyi 'tiaptiap warga berhak dan wajib ikut serta dalam usaha pertahanan dan keamanan Negara'.

Dalam Undang-undang RI Nomor 34 Tahun 2004 tentang Tentara Nasional Indonesia (TNI), disebutkan bahwa Tentara Nasional Indonesia (TNI) sebagai Alat Negara di bidang Pertahanan yang dalam menjalankan tugasnya berdasarkan kebijakan dan keputusan Politik Negara. Disamping peran tersebut, Tentara Nasional Indonesia juga mempunyai tugas yakni menjaga kedaulatan Bangsa dan Negara dengan mempertahankan keutuhan negara berdasar Pancasila dan Undangundang Dasar 1945 dan juga melindungi seluruh elemen bangsa dengan tumpah darah dari berbagai ancaman baik dalam maupun luar negeri.

Keikutsertaan warga Negara dalam usaha Bela Negara merupakan hak dan kewajiban konstitusional yang diwujudkan dalam sikap dan perilaku yang dijiwai kecintaan akan Bangsa dan Negara dalam menjamin keberlangsungan hidup Bangsa dan Negara. Program Bela Negara merupakan program inisiatif Kementerian Pertahanan yang juga adalah Program Nasional, program tersebut dimulai pada bulan Oktober tahun 2015. Undang-undang Pertahanan Negara juga mengklasifikasikan bahwa Pertahanan Negara yang digolongkan pada 3 (tiga) kelompok, yakni Komponen Utama (TNI), Komponen Cadangan dan Komponen Pendukung. Undang-undang RI Nomor 3 Tahun 2002 Pasal 9 ayat (2) juga menjabarkan bahwa keikutsertaan Warga Negara dalam upaya Bela Negara, diselenggarakan melalui Pendidikan Kewarganegaraan, Pelatihan Dasar Kemiliteran secara wajib, Pengabdian sebagai prajurit TNI dan Pengabdian sesuai dengan Profesi.

TNI AD sebagai sebagai Alat Pertahanan Negara di darat memiliki fungsi dalam penyelenggaraan Organisasi, diantaranya Fungsi utama, Fungsi Organik Militer, Fungsi Teknis Militer umum, Fungsi Teknis Militer Khusus dan Fungsi Khusus. Penyelenggaraan Pembinaan Pemberdayaan Wilayah Pertahanan di darat beserta Kekuatan Pendukung lainnya merupakan fungsi 
Organik Militer TNI AD dalam hal ini merupakan Fungsi Teritorial. Pelaksanaan Fungsi Teritorial TNI AD merupakan Tugas Pokok dari Staf Teritorial TNI AD dan dalam teknis pelaksanaannya dikoordinir oleh Pusat Teritorial TNI AD (Pusterad).

Era Globalisasi dan pesatnya Perkembangan Teknologi yang dikemas dalam bentuk-bentuk yang sangat menarik membuat Generasi Muda cepat terpengaruh dan terbawa dengan arus Globalisasi dan Perkembangan Teknologi. Di satu sisi pada usia SMA dan bangku kuliah Generasi Muda saat ini sedang mencari jati dirinya sendiri. Hal inilah yang akan menjadi hakekat ancaman bagi Keutuhan Negara Kesatuan Republik Indonesia (NKRI) apabila Generasi Muda mengadopsi Budaya Asing tanpa memilah apa yang boleh dan tidak boleh sedangkan mereka tidak mengenal dengan baik budaya Bangsa Indonesia (budaya Timur).

Dari hasil pengamatan peneliti dilapangan, Implementasi Bela Negara di wilayah Komando Distrik Militer 1309/Manado dijalankan dengan beberapa program kegiatan Komunikasi Sosial yang bekerjasama dengan Kesbangpol Prov Sulut, membaur dengan siswa-siswa Sekolah Menengah Atas di kota Manado dengan kegiatan pendalaman Wawasan Kebangsaan serta latihan upacara di Kodim 1309/Manado, pembinaan Wawasan Kebangsaan (Wasbang) di kantor-kantor Camat yang diikuti berbagai elemen masyarakat.

Fenomena saat ini di Kalangan Muda adalah Generasi Muda sudah terbawa dengan dengan arus Globalisasi dan Perkembangan Teknologi yang membuat mereka cenderung bersikap Individual dan Anarkis. Saat ini kita bisa melihat di tempat-tempat publik Generasi Muda yang asik dengan Gadget mereka masing- masing dan tanpa menghiraukan lingkungan di sekelilingnya untuk bersosialisasi. Kita juga bisa melihat banyak Generasi Muda mendatangi tempat-tempat game online atau juga mereka bermain game online di handphone mereka. Fenomena itu akan menjadi ancaman serius bagi Generasi Muda Indonesia pada umumnya dan rasa Nasionalisme serta Cinta Tanah Air pada khususnya yang akan berdampak secara langsung pada Ketahanan Nasional. Dampak dari pengaruh Globalisasi dan Perkembangan Teknologi terhadap Generasi Muda yang tidak memiliki kecintaan pada Budaya Indonesia membuat mereka cepat mengadopsi budaya Barat dan cenderung bersikap Individual dan Anarkis.

Salah satu kejadian yang belum lama ini terjadi di wilayah Kota Manado adalah pengeroyokan dan penikaman terhadap seorang Guru Agama SMK Ichtus Desa Koka, Mapanget Barat, Manado. Dalam kejadian tersebut AW seorang Guru Agama dikeroyok dan ditikam hingga tewas oleh seorang Pelajar yang berinisial FL yaitu seorang Pelajar di sekolah tersebut. Kejadiannya bermula ketika Pelajar tersebut ditegur Guru Agama karena merokok di lingkungan sekolah. Karena tersinggung di tegur, Pelajar tersebut mengeroyok dan menikam Guru Agamanya tersebut sampai meninggal dunia. Kejadian ini secara tidak langsung memberikan gambaran tentang kondisi Generasi Muda saat ini yang sudah terkontaminasi dengan budaya Asing tanpa melihat Budaya tersebut cocok atau tidak dengan Budaya kita sendiri (Budaya Bangsa Indonesia).

\section{Implementasi Kebijakan}

"Secara etimologis implementasi itu dapat dimaksudkan sebagai suatu aktivitas yang bertalian dengan penyelesaian suatu pekerjaan dengan penggunaan sarana (alat) untuk memperoleh hasil. Lebih lanjut dikatakan bahwa, apabila pengertian implementasi ini dirangkaikan dengan kebijakan publik maka kata implementasi kebijakan publik dapat diartikan sebagai aktivitas penyelesaian atau pelaksanaan suatu kebijakan publik yang telah ditetapkan/disetujui dengan penggunaan sarana (alat) untuk mencapai tujuan kebijakan" (Tachjan, 2008:24)

Mazmanuan menyatakan "Implementasi adalah pelaksanaan keputusan kebijakan dasar, yang biasanya dalam bentuk undang- undang, namun dapat pula berbentuk perintah-perintah atau keputusan-keputusan eksekutif legislatif yang penting atau keputusan badan peradilan" Wahab, 2001:68).

$$
\text { Implementasi kebijakan (policy }
$$
implementation) merupakan proses lebih lanjut dari tahap formulasi kebijakan. Pada tahap formulasi ditetapkan strategi dan tujuan kebijakan, sedangkan tindakan (action) untuk mencapai tujuan diselenggarakan pada tahap implementasi kebijakan. Di negara maju umumnya suatu kebijakan diperdebatkan pada saat formulasi dalam parlemen karena masyarakat diikutsertakan sehingga apabila kebijakan sudah dikeluarkan tidak ada lagi perdebatan dalam masyarakat. Sedangkan di negara berkembang diperdebatkan di masyarakat pada saat implementasi karena rakyat tidak diikutsertakan di dalam perumusan kebijakan. Dalam kaitan ini, Tachjan (2006 : vi) menegaskan bahwa : "Implementasi kebijakan publik adalah proses yang kompleks, melibatkan dimensi organisasi, kepemimpinan, bahkan manajerial dari pemerintah sebagai pemegang otoritas". Kompleksnya masalah implementasi kebijakan dikemukakan pula oleh Agustino (2006:153) bahwa : "Dalam praktiknya implementasi kebijakan merupakan suatu proses yang begitu kompleks bahkan tidak jarang 
bermuatan politis karena adanya intervensi dari berbagai kepentingan".

Secara konseptual terdapat beberapa model mengenai implementasi kebijakan, Edward III (1980:9-10) berpendapat bahwa di dalam proses implementasi kebijakan, dimensi komunikasi memegang peranan penting disebabkan pelaksana harus mengetahui segala yang dikerjakan. Setiap perintah yang disampaikan di dalam rangka melaksanakan kebijakan harus diteruskan kepada perangkat secara tepat dan konsisten. Kurangnya sumber daya berakibat ketidakefektifan penerapan kebijakan. Disposisi atau sikap pelaksana diartikan sebagai keinginan adanya kesepakatan di kalangan pelaksana untuk menerapkan kebijakan.

Apabila penerapan kebijakan dilaksanakan secara efektif, maka pelaksana bukan hanya sekedar mengetahui segala yang seharusnya dikerjakan dan berkemampuan menerapkannya, tetapi harus mempunyai keinginan untuk menerapkan kebijakan tersebut. Struktur birokrasi memiliki dampak atas penerapan kebijakan. Implementasi kebijakan menurut Edward III dijelaskan pada Gambar 1.

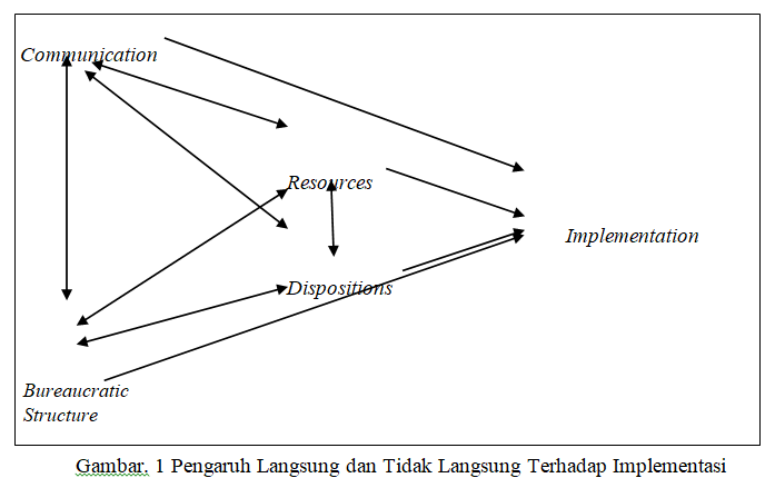

Gambar. 1 Pengaruh Langsung dan Tidak Langsung Terhadap Implementa
Sumber. George III Edward :implemeting public policy, 1980

Implementasi kebijakan pada dasarnya juga mengukur akan keberhasilan atau kegagalan suatu hasil kebijakan yang secara nyata dilaksanakan dilapangan oleh para implementator dan bagaimana dampaknya terhadap masyarakat maupun stakeholder-nya, sebagaimana dikemukakan oleh Saefullah (2007:39) "pada tingkat pelaksanaan kebijakan menyangkut bagaimana atau sejauhmana suatu kebijakan bisa dilaksanakan dalam dunia nyata". Pemahaman tentang pelaksanaan kebijakan bukan hanya dimiliki oleh aparat lembaga dan aparat pelaksana, tetapi juga oleh masyarakat atau pihakpihak yang menjadi sasaran kebijakan".

Pada tataran lain, implementasi kebijakan publik (public policy implementation) lebih merupakan salah satu tahapan dari proses kebijakan publik. Beragam dinamika peristiwa dan permasalahan terjadi merupakan hasil dari hadirnya keputusan pemerintah yang berdampak dari implementasi kebijakan negara. Dengan mencermati implementasi kebijakan, berarti adanya usaha secara aktif untuk memprediksi segala kejadian sesudah kebijakan itu diimplementasikan di dalam lingkungan pemerintahan.

Berdasarkan pendapat dari para ahli yang telah dikemukakan, maka disimpulkan bahwa implementasi kebijakan merupakan elemen penting yang melibatkan banyak elemen yang terkait satu sama lain yang memiliki tujuan yang sama. Implementasi kebijakan juga dipengaruhi oleh situasi dan kondisi yang berlaku, setiap situasi berbeda penanganannya dan juga berbeda hasil yang dihasilkannya.

\section{Bela Negara}

Dalam Konteks Kemiliteran di Indonesia, sesuai amanat Undang-undang TNI terkait dengan Operasi Militer Selain Perang (OMSP), setiap Satuan Komando Kewilayahan (Satkowil) diberikan Tugas yang salah satunya adalah Perbantuan terhadap Pemerintah Daerah (Pemda). Tugas tersebut dilakukan melalui Pembinaan Teritorial (Binter), yakni upaya pengelolaan Pertahanan di Daerah melalui Pendekatan atau Metode Pembinaan dari Aspek Komunikasi Sosial, Ketahanan Wilayah dan Bakti TNI. Melalui Pelaksanaan Tugas Perbantuan terhadap Pemerintah Daerah (Pemda), Satuan Komando Kewilayahan (Satkowil) memainkan perannya dalam mendorong proses Pembangunan di daerah yang berkorelasi dengan terpenuhinya berbagai Kepentingan Publik. Pada umumnya, masyarakat menilai keberadaan berbagai Satuan Teritorial TNI AD di lingkungan mereka bermanfaat untuk menciptakan Stabilitas Keamanan. Keberadaan Institusi Teritorial juga berperan dalam menengahi berbagai kelompok masyarakat yang terdiri dari berbagai kepentingan yang terkadang sulit disatukan dan acapkali menimbulkan pergesekan Sosial. Karena itu secara sosiologis, TNI telah berupaya melakukan restrukturisasi fungsi di tengah-tengah masyarakat yaitu dengan memposisikan diri sebagai pihak yang turut menciptakan keteraturan Sosial (Herdiansah dkk, 2017).

Teritorial pada hakekatnya merupakan penjabaran dari Peraturan Perundang-undangan dan ketetapan-ketetapan yang mengatur tentang Hak Pembelaan Negara serta Sistem Pertahanan dan Keamanan Negara (Sishankamneg) yang menjadi Fungsi dan Peran TNI AD. Pembinaan Teritorial (Binter) bercirikan Kewilayahan, Kerakyatan dan Kesemestaan, sehingga dalam pelaksanaannya 
melibatkan seluruh Komponen Bangsa. Wujud Pembinaan Teritorial merupakan suatu sistem Pembinaan yang digali dari Pengalaman Bersenjata untuk menegakkan Keutuhan Negara dengan berpegang teguh pada Konstitusi yakni Pancasila dan UUD 1945. Dalam Perjuangan TNI, Pembinaan Teritorial (Binter) telah teruji aktivitasnya untuk menangkal berbagai Peristiwa Nasional maupun Sektoral yang bercorak Kewilayahan sehingga dapat digunakan sebagai upaya untuk mengelola Potensi Kewilayahan. Konsepsi Pembinaan Teritorial (Binter) dalam mengelola Kekuatan Pertahanan di daerah yang dikembangkan TNI pada saat ini berbeda dengan konsep lama (Hankamrata), melainkan sesuai konsep Pertahanan menyeluruh (total defence). Dalam konsepsi Hankamrata, rakyat menjadi "pagar manusia" di bidang Pertahanan dan Keamanan (Hankam). Sementara dalam total defence, rakyat diberi Pelatihan dan Keahlian, sehingga dapat menjadi Kekuatan Pendukung Pertahanan Negara (Wibowo, 2015)

Seiring dengan Reformasi menuju Kehidupan yang lebih Demokratis dalam era Globalisasi, telah muncul Kelompok-kelompok masyarakat untuk berupaya menjadikan beberapa Masalah Nasional menjadi Masalah Internasional, kondisi ini menyebabkan semakin Kompleksnya Permasalahan yang dihadapi oleh Bangsa Indonesia saat ini, demikian pula terhadap Organisasi TNI. Kecenderungan terhadap TNI yang muncul akan adanya tuntutan perubahan yang segera. Keputusan Politik yang mengatur pelaksanaan Operasional Peran TNI telah ditetapkan, yakni Tap MPR RI No. VI/MPR/2000, Tap MPR RI No. VII/MPR/2000, yang mengatur Pemisahan TNI dan Polri serta mengatur Peran TNI dalam Fungsi Pertahanan dan Peran Polri dalam Fungsi Keamanan.

Sikap masyarakat selalu mengkritisi dan memojokkan TNI dalam posisi terjepit dan dilematis, TNI seolah terpisah dari rakyat, menyikapi Perkembangan situasi yang begitu pesat dihadapkan dengan Kesiapan Wilayah yang selama ini dibina oleh Satuan Komando Kewilayahan (Satkowil), sehingga dalam hal ini Fungsi Pembinaan Teritorial (Binter) menjadi lebih penting mengingat tantangan dan Dinamika Kehidupan di daerah dapat membuka Peluang bagi terciptanya kerawanan yang mengganggu Stabilitas Keamanan. Oleh karena itu, Penyelenggaraan Binter dalam mewujudkan Fungsi Binter sangatlah penting untuk dapat dijadikan Landasan yang kuat bagi terciptanya Ketahanan Wilayah dan juga sekaligus dapat mendukung Kepentingan Sishanta (Tjandrawati dkk, 2010).
Masalah Teritorial dan penanganannya di Indonesia membutuhkan sesuatu pendekatan yang spesifik melalui suatu prosedur 'Geostrategi' yang baik, agar diperoleh : 1) Pembinaan Wilayah yang dapat menciptakan Ketahanan Nasional yang maksimal dan efektif di berbagai bidang (Ideologi, Politik, Ekonomi, Sosial, Budaya, Militer, Kehidupan beragama dan keberlanjutan Pembangunan Nasional), 2) Faktor Kesejahteraan dan Keamanan Bangsa dan 3) PembinaanTeritorial yang menitikberatkan pada penyusunan potensi Pertahanan dan Keamanan (Hankam), (Danpusterad, 2011). Ditinjau dari Perspektif Kritis isu Aktual tersebut sangat menarik, Pembinaan Teritorial bagi TNI adalah upaya, pekerjaan dan tindakan, baik secara berdiri sendiri maupun bersama dengan Aparat terkait dan Komponen Bangsa lainnya untuk membantu Pemerintah dalam menyiapkan Kekuatan Pertahanan matra darat, laut dan udara, yang meliputi Wilayah Pertahanan dan Kekuatan Pendukungnya serta terwujudnya Kemanunggalan TNI dan rakyat, yang dilaksanakan sesuai Kewenangan dan Peraturan Perundang-undangan dalam rangka tercapainya Tugas Pokok TNI (Samego, 2001). Demikian pula hal ini secara signifikan berdampak pada struktur Organisasi Komando Distrik Militer (Kodim) di daerah yang terpengaruh menjadi fokus pada Fungsi Pertahanan yang tadinya juga menangani Keamanan dalam arti luas maupun Keamanan Ketertiban Masyarakat (Makalassa S, 2005).

Doktrin TNI AD Kartika Eka Paksi yang dijabarkan dalam Buku Petunjuk Teknis Binter (2016), Pembinaan Teritorial (Binter) merupakan upaya Pekerjaan dan Tindakan, baik secara berdiri sendiri maupun bersama-sama dengan Aparat terkait dan Komponen Bangsa lainnya untuk membantu Pemerintah dalam menyiapkan Kekuatan Pertahanan Aspek Darat yang meliputi Wilayah Pertahanan dan Kekuatan Pendukung lainnya serta terwujudnya Kemanunggalan TNI dengan Rakyat, yang dilaksanakan sesuai Kewenangan dan Peraturan Perundang-undangan dalam rangka Kepentingan Pertahanan Negara matra darat.

Purnomo Yusgiantoro (2014) dalam ceramah Pemantapan Nilai-nilai Kebangsaan di Lemhannas RI . Beratnya tantangan yang dihadapi Generasi Muda, harus pula disikapi dengan menjaga keseimbangan antara Kecerdasan Intelektual dengan Kecerdasan Emosional maupun Kecerdasan Spiritual. Keseimbangan ketiga faktor tersebut, diharapkan akan mewujudkan perilaku Kalangan Muda yang senantiasa menjunjung tinggi Moral dan Etika, Kejujuran dan Kebangsaan. Tanpa keseimbangan ketiga faktor tersebut, kecerdasan yang dimiliki Generasi Muda justru akan 
menggerogoti Sendi-sendi Kehidupan Bangsa. Kemampuan inilah yang sesungguhnya merupakan wujud Bela Negara dalam spektrum yang harus dilakukan oleh Kalangan Muda di masa damai.

\section{Ketahanan Nasional}

Menurut Tiara Andita pada Konsep Ketahanan Nasional Serta Peran Masyarakat Dalam Mewujudkannya (https://www.kompasiana.com/ tiaraandita), bahwa Indonesia sering sekali mendapat beberapa ancaman yang datang dari dalam maupun luar negeri, dikarenakan Indonesia masih dalam kondisi yang sangat kritis. Namun, hal ini dengan seiring berjalannya waktu, Indonesia dapat mengatasi semua ancaman dan masalah yang ada. Dengan adanya tekad bersama yang membuat Bangsa Indonesia bersatu untuk memBela Negara tercintanya ini. Salah satu contoh pemberontakan yang terjadi di dalam negeri ini adalah PKI, RMS, PRRI Permesta dan gerakan separatis di TimorTimur/Timor Leste (RDTL). Melihat kondisi ini, maka sangat diperlukan kondisi dimana Bangsa Indonesia merasa aman dan selalu mempunyai antisipasi untuk mencegah terjadinya hal-hal yang tidak diinginkan dalam Negara Indonesia ini.

Ketahanan Nasional adalah kondisi dinamis suatu Bangsa yang terdiri atas ketangguhan serta keuletan dan kemampuan untuk mengembangkan Kekuatan Nasional dalam menghadapi segala macam dan bentuk masalah, ancaman, tantangan, hambatan yang datang dari dalam maupun dari luar, baik secara langsung maupun tidak langsung yang membahayakan kelangsungan hidup Bangsa Indonesia serta perjuangan dalam mewujudkan tujuan Perjuangan Nasional. Dari pengertian yang telah dikemukakan sebelumnya maka dapat disimpulkan bahwa Ketahanan Nasional di Indonesia sangat diperlukan. Ini dimaksudkan agar Bangsa Indonesia dapat melangsungkan Kehidupannya yang sejahtera, merasa aman, jauh dari ancaman, tetapi harus selalu tetap waspada terhadap apa yang terjadi. Ini tidak hanya diperlukan oleh Negara Indonesia saja, bahkan seluruh Negara yang ada dimuka bumi ini pun membutuhkannya.

Berbicara tentang Ketahanan Nasional, ini juga mempunyai beberapa sifat yang harus di ketahui, diantaranya: (1). Mandiri, sifat mandiri yang berarti bisa melakukan sendiri. Bangsa Indonesia percaya akan kekuatan yang mereka punya untuk melindungi Negaranya dari segala macam bentuk ancaman. Tentu hal ini Persatuan-lah yang sangat mendasari.; (2). Dinamis, Ketahanan Nasional tidak lah tetap pada kondisi yang itu saja, ini juga dapat terus semakin meningkat atau menurun, tergantung pada situasi dan kondisi
Negaranya.; (3). Manunggal, ini diartikan memiliki perpaduan yang sangat baik, seimbang dan serasi antara seluruh aspek yang meliputi bangsa serta Negara Indonesia; (4). Wibawa, dengan adanya sifat manunggal ini maka berdampak baik untuk Bangsa serta Negara Indonesia. Karena itu dapat diperhitungkan oleh pihak lain yang membuat Indonesia dapat membawa Negara-nya kearah yang lebih baik serta memiliki daya tangkal yang besar. Karena semakin baik daya tangkalnya, maka semakin baik pula kewibawaannya. ; (5). Konsultasi dan kerjasama, mendengar kata konsultasi dan kerjasama pasti yang ada dalam pikiran kita adalah saling mendengarkan pendapat orang lain dan selalu bekerja bersama-sama dalam melindungi Negaranya. Ya hal ini dibuktikan dengan tidak adanya sikap yang antagonis terhadap Bangsa Indonesia yang satu dengan yang lainnya. Karena Bangsa Indonesia lebih mengutamakan Persatuan dari pada melakukan sendiri-sendiri.

Selain sifatnya, Ketahanan Nasional juga mempunya beberapa asas yang sangat penting. Sebelumnya pengertian dari asas Ketahanan Nasional itu adalah tata laku yang didasari nilai yang berlaku di Pancasila UUD 1945 serta Wawasan Nusantara. Menurut Lemhanas (Lembaga Ketahanan Nasional) asas-asas tersebut adalah: (1). Asas kesejahteraan dan Keamanan, seperti yang telah dijelaskan diatas, kesejahteraan dan keamanan adalah hal yang paling mendasar yang harus didapatkan Bangsa Indonesia sebagai warga Negaranya. Biasanya ini menjadi tolak ukur mantap atau tidaknya Ketahanan Nasional di Negara tersebut.; (2). Asas Komprehensif/menyeluruh terpadu, asas ini memiliki arti yaitu Ketahanan Nasional mencakup seluruh aspek yang sangat berkaitan satu sama lain yang mempunyai sifat serasi selaras dan terpadu satu sama lainnya.; (3). Asas Kekeluargaan, dalam asas ini mempunyai pengertian bahwa kita harus saling tolong-menolong, bersikap adil, saling tenggang rasa dalam Kehidupan bernegara dan bermasyarakat. Hal ini sangat dibutuhkan untuk menjaga Persatuan Bangsa Indonesia satu dengan yang lainnya.

Bukan hanya itu saja, Ketahanan Nasional juga mempunyai kedudukan dan fungsi yang perlu diketahui, diantaranya adalah: (1). Kedudukan, Ketahanan Nasional berkedudukan sebagai landasan konseptual yang didasari oleh Pancasila sebagai landasan ideal dan UUD 1945 sebagai landasan Konstitusional dalam paradigma Pembangunan Nasional. Jadi, Ketahanan Nasional ini juga memiliki konsep yang harus dipatuhi oleh masyarakat, kita jangan seenaknya saja dalam hal ini karena berkonsep lah yang dapat mengarahkan 
kearah yang baik agar tidak salah jalan.; (2). Fungsi, Ketahanan Nasional dalam fungsinya adalah sebagai Dasar Nasional perlu dipahami untuk menjamin terjadinya pola pikir, pola tindak dan pola kerja dalam menyatukan langkah bangsa yang bersifat inter-regional, inter-sektoral dan multi-disiplin. Maksudnya disini adalah Ketahanan Nasional memiliki fungsi yang harus dilaksanakan untuk menciptakan pola pikir, pola tindak dan pola kerja masyarakat dalam menciptakan kondisi yang dinamis tuntuk mengantisipasi terjadinya hal yang tidak diinginkan. Karena dengan adanya fungsi ini, masyarakat bisa saling berintegrasi satu sama lainnya untuk selalu menjaga dan melindungi Bangsa dan Negara-nya.

Dalam Ketahanan Nasional ini sesungguhnya masih banyak yang harus kita ketahui, dan sekarang yang akan kita bahas tentang konsepsi Ketahanan Nasional, antara lain adalah: (1). Ketangguhan, ketangguhan yang dimaksud disini adalah ketangguhan seseorang untuk dapat bertahan kuat dalam beban atau masalah yang menggelutinya. Ini sangat kita perlukan agar kita bisa menjadi orang yang tidak gampang putus asa dan selalu semangat dalam menjalankan Kehidupannya sehari-hari.; (2). Keuletan, yaitu kerja keras/usaha yang kita lakukan untuk mencapai tujuan yang kita inginkan. Menjadi seseorang yang ulet itu sangat baik, karena dia bisa menaklukan semua rintangan/tantangan yang ada dihadapannya dengan mudah, ya walaupun sedikit memerlukan kerja keras tapi ini sangat baik.; (3). Identitas, adalah ciri khas suatu Bangsa atau Negara secara keseluruhan. Dalam Kehidupan di Negara ini, kita sebagai Warga Negara Indonesia mempunyai bermacam-macam ciri khas yang sangat unik. Tetapi, itu semua yang menjadikan Negara Indonesia adalah Negara yang memiliki banyak keragaman.; (4). Integritas, ialah kesatuan menyeluruh dalam Kehidupan Nasional suatu Bangsa baik unsur Sosial maupun Alamiah, baik bersifat Potensial maupun Fungsional.; (5). Ancaman, ancaman yang dimaksud disini bukanlah ancaman pada hakikatnya, melainkan usaha yang bersifat merombak kebijaksanaan yang dilakukan secara Konseptual, Kriminal dan Politis.; (6). Hambatan dan Gangguan, adalah hal/usaha yang berasal dari luar maupun dari dalam diri sendiri. Ini dimaksudkan agar kita dapat mengontrol diri kita ketika kita mengalami hambatan serta gangguan yang menimpa diri kita sendiri.

Setelah kita melihat keseluruhan yang berhubungan dengan Ketahanan Nasional, maka kita dapat menyimpulkan bahwa Ketahanan Nasional ini membutuhkan pembinaan yang terpadu satu sama lain, antara lain: (1). Meningkatkan dan pengembangan Pancasila yang objektif maupun subjektif.; (2). Pancasila sebagai Ideologi terbuka perlu terus direlevansikan dan diaktualisasikan.; (3). Bhinneka Tunggal Ika dan konsep Wawasan Nusantara bersumber dari Pancasila dan UUD 1945.; (4). Pancasila sebagai pandangan hidup bangsa dan dasar Negara Republik Indonesia harus dihayati dan diamalkan secara nyata.; (5). Pembangunan sebagai pengamalan Pancasila harus menunjukkan keseimbangan fisik material dengan pembangunan mental utnuk menghindari tumbuhnya materialism dan sekularisme.; (6). Pendidikan moral Pancasila ditanamkan pada diri anak didik dengan cara mengintegrasikan ke dalam mata pelajaran lain di sekolah.

Dengan demikian dapat disimpulkan bahwa Ketahanan Nasional itu juga memiliki konsep untuk melakukannya. Kita sebagai Bangsa Indonesia ini pun juga sebaiknya dapat merealisasikannya untuk mencapai titik kesejahteraan serta Keamanan di Indonesia ini. Karena Indonesia selalu menjunjung tinggi Persatuan dan Kesatuan satu sama lainnya.

Berdasarkan uraian latar belakang dan landasan teori yang telah dikemukakan menyangkut kondisi Global Bangsa Indonesia saat ini dalam era Modernisasi dihadapkan dengan fenomena pergeseran nilai-nilai Nasionalisme Generasi Muda, maka penelitian ini difokuskan pada "Implementasi Kebijakan Bela Negara untuk mewujudkan Ketahanan Nasional di wilayah Komando Distrik Militer 1309/Manado".

\section{Rumusan Masalah}

Rumusan masalah penelitian ini adalah Mengapa Implementasi kebijakan Bela Negara untuk Mewujudkan Ketahanan Nasional di Wilayah Komando Distrik Militer 1309/Manado belum berjalan optimal?

\section{Tujuan Penelitian}

Tujuan penelitian yaitu menganalisis Implementasi kebijakan Bela Negara untuk Mewujudkan Ketahanan Nasional di Wilayah Komando Distrik Militer 1309/Manado yang dilaksanakan oleh Satuan Komando Kewilayahan (Satkowil) yaitu Kodim 1309/Manado, Korem 131/Stg dan Kodam XIII/Mdk dalam rangka mewujudkan Ketahanan Nasional secara umum dan secara khusus di daerah Kota Manado dan sekitarnya.

\section{Manfaat Penelitian}

Dari aspek teoritis, diharapkan dapat memberikan Kontribusi untuk Ilmu Pengetahuan khususnya pengembangan Pembinaan Teritorial (Binter) di lingkungan Satuan Komando 
Kewilayahan (Satkowil) TNI AD dan di Program Studi Pengelolaan Sumber Daya Pembangunan, pada minat Ilmu Pemerintahan.

Dari aspek praktis, penelitian ini mampu memberikan masukan kepada Satuan Komando Kewilayahan (Satkowil) pada umumnya dan Kodim 1309/Manado, Korem 131/Stg dan Kodam XIII/Mdk dalam Pembinaan Teritorial (Binter) di jajarannya dalam rangka mewujudkan Ketahanan Nasional.

\section{METODE PENELITIAN}

Pendekatan yang digunakan dalam Penelitian ini adalah pendekatan Deskriptif Kualitatif. Hal terpenting dalam sebuah Penelitian adalah memilih dan menetapkan Paradigma Penelitian yang akan dijadikan panduan selama Proses Penelitian. Penelitian ini dilakukan di Kodim 1309/Manado Korem 131/Stg Kodam XIII/Mdk dimulai dari Observasi awal yang Peneliti lakukan di Lokasi Penelitian pada bulan Desember 2019 sampai dengan bulan Februari 2020. Pengumpulan data pada penelitian ini dilakukan dengan 3 (tiga) kegiatan utama yaitu Wawancara, Observasi dan Dokumentasi. Data Primer diperoleh dengan Menggunakan Metode Observasi dan Wawancara. Sementara Data Sekunder dalam penelitian ini dikumpulkan dari berbagai dokumen yaitu segala hal yang berhubungan dengan Konsep, Teori dan Referensi-referensi yang berkaitan dengan Pertahanan dalam Aspek Darat. Informan dalam penelitian ini dipilih secara sengaja sesuai dengan tujuan penelitian yaitu: Komandan Komando Distrik Militer (Dandim) 1309/Manado 1 orang, Kepala Staf Kodim (Kasdim) 1309/Manado 1 orang, Perwira Seksi Teritorial (Pasiter) Kodim 1309/Manado 1 orang, Komandan Komando Rayon Militer (Danramil) 5 jajaran Kodim 1309/Manado 5 orang, Anggota Bintara Pembina Desa (Babinsa) jajaran Kodim 1309/Manado 2 orang, Masyarakat 5 orang. Analisis data menggunakan tehnik analisis data kualitatif yang dimulai dengan Mengumpul data di Lapangan, setelah itu melakukan Reduksi data (Data Reduction), Menyajikan data (Data Display) dan Akhirnya menarik Kesimpulan dan Verifikasi (Conclusion Drawing/verification).

\section{PEMBAHASAN}

Bela Negara merupakan hak dan kewajiban setiap Warga Negara dalam rangka mempertahankan Kedaulatan Negara sebagaimana diatur dalam UUD 1945 Pasal 27 ayat (3) dan Pasal 30 ayat (1), Undang-undang Nomor 3 tahun 2002 Pasal 9 ayat (1) tentang Pertahanan Negara. Untuk dapat mewujudkan ketentuan tentang keikutsertaan Warga Negara dalam Bela Negara diperlukan Pembinaan secara intensif dan berkelanjutan. Upaya Pembinaan kesadaran Warga Negara dalam Bela Negara merupakan kewajiban Pemerintah selaku Penyelenggara Negara dan TNI sebagai Komponen utama sistem Pertahanan Negara. Pelibatan TNI dalam upaya Pembinaan kesadaran masyarakat dalam Bela Negara dalam hal ini dilaksanakan oleh Satuan Komando Kewilayahan (Satkowil) yaitu Kodim 1309/Manado. Pembinaan Bela Negara yang dilaksanakan oleh jajaran Kodim 1309/Manado bertujuan untuk mewujudkan kesadaran Bela Negara bagi setiap Warga Negara di wilayah Kodim 1309/Manado yang meliputi wilayah Kota Manado, sebagian wilayah Kabupaten Minahasa dan Kabupaten Minahasa Utara dalam rangka mendukung kepentingan Pertahanan Negara. Adapun yang menjadi sasaran Program Pembinaan Bela Negara adalah terwujudnya kesadaran Bela Negara di kalangan masyarakat melalui Pendidikan atau Pelatihan formal dan kegiatan non formal dalam rangka mendukung kepentingan Pembangunan Wilayah dan kepentingan Pertahanan Negara serta Ketahanan Nasional di Kota Manado, sebagian wilayah Kabupaten Minahasa dan Kabupaten Minahasa Utara. Namun dalam hasil wawancara terhadap sejumlah Informan, bahwa sampai saat ini penerapan Pembinaan Bela Negara di jajaran Kodim 1309/Manado belum berjalan efektif karena di hadapkan dengan berbagai permasalahan diantaranya dari pihak Penyelenggara sendiri (Kodim 1309/Manado dan Koramil Jajarannya) masih memiliki kendala dalam hal jumlah Personel. Penyelenggara yang relatif masih terbatas sekitar $60-65 \%$ dari jumlah Personel yang seharusnya ada di hadapkan dengan banyaknya kegiatan yang harus dilaksanakan secara bersamaan.

Disamping keterbatasan Personel kendala lain dari pihak Penyelenggara adalah kurangnya Personel yang mengetahui pemahaman atau pengetahuan serta kualifikasi dalam bidang Wawasan Nusantara dan Bela Negara serta terbatasnya buku atau referensi untuk mendukung pelaksanaan kegiatan Bela Negara. Dari pihak masyarakat sebagai sasaran pelaksanaan kegiatan Bela Negara, berdasarkan wawancara yang dilaksanakan bahwa masyarakat dan pihak sekolah sendiri sangat mengharapkan pelaksanaan kegiatan Bela Negara yang berkesinambungan dalam rangka membina masyarakat serta para Pelajar di sekolah. Kendala lain yang dihadapi adalah karena Program Bela Negara belum di masukan dalam Kurikulum Pendidikan 6 sekolah mulai dari SD sampai dengan tingkat Perguruan Tinggi. Sehingga menjadi kendala bagi pihak sekolah dan Koramil sebagai Pelaksana di wilayah untuk merealisasikan Pelaksanaan Bela 
Negara di hadapkan dengan materi Bela Negara dan perbedaan tingkat Pendidikan. Dari hasil wawancara yang dilaksanakan kepada para Informan baik dari pihak Jajaran Kodim 1309/Manado dan masyarakat wilayah Kodim 1309/Manado pada dasarnya kegiatan Bela Negara sudah dilaksanakan sesuai program yang ditentukan akan tetapi belum efektif dan belum menyentuh seluruh lapisan masyarakat, hal ini disebabkan karena faktor Personel, kualifikasi dan faktor pendukung lainnya seperti Komponen Pendidikan dan Komponen Pemerintahan Daerah (Pemda) selain itu faktor kontinuitas program dalam keseharian mereka merupakan factor yang masih diperlukan agar pengaruh-pengaruh negative dapat ditangkal sedini mungkin.

Aspek komunikasi dengan segala rincian dan bentuknya adalah sesuatu kegiatan yang sangat penting bagi upaya membangun pemahaman, kesadaran dan kemudian kepatuhan dalam memenuhi atau melaksanakan sebuah kewajiban publik. Diantara kewajiban publik itu adalah kewajiban bela Negara yang telah diatur dalam perundang-undangan, namun tidak banyak mengetahui dan menyadari kewajiban tersebut, semangat nasionalisme yang semakin tergerus oleh perkembangan zaman serta keadaan ,aman "e yang meninabobokan banyak kalangan. Oleh karena ketentuan yang telah ditetapkan perlu dikomunikasikan. Dalam sistem pemerintahan yang demokratis dan tata kelola pemerintahan yang baik, maka tujuan komunikasi kebijakan publik adalah untuk menciptakan kesadaran yang kemudian berujung pada kepatuhan masyarakat dalam melaksanakan kewajibannya. Pada saat ditanya kepada informan dan juga kepaa pada masyarakat pada umumnya tentang tingkat pemahaman mereka dapat dipastikan beragam. Namun jika dilihat dari gambaran perilaku anak muda di Kota Manado dapat terlihat masih banyak generasi muda yang lalai dalam menerapkan konseo bela Negara dan bahkan tidak tahu mengenai bela Negara. Jika ujungnya bukan pada kepatuhan, maka tidak otomatis kegiatan komunikasi itu dianggap gagal karena banyak aspek yang membuat seseorang itu patuh (compliance) akan kewajiban publik yang harus dilaksanakan.

Lain halnya jika kriteria kesadaran atau pengatahuan akan bela Negara itu yang masih rendah, maka kegiatan komunikasi ini yang harus ditingkatkan kuantitas dan kualitasnya. Ada sejumlah kegiatan komunikasi berupa sosialisasi yang bisa tergolong intensif, dengan menggunakan berbagai cara, tetapi hasilnya seringkali tidak berhubungan dengan meningkatnya sebuah kepatuhan. Hal ini meneguhkan pendapat bahwa ada sejumlah faktor lain yang mendorong seseorang itu patuh melaksanaan sebuah kewajiban yang sudah disadari akan keberadaannya. Bentuk komunikasi bela Negara kepada masyarakat banyak diharapkan juga agar dapat diubah metodenya atau juga dapat berinovasi bentuknya dan juga bersifat berkelanjutan agar komunikasi materi tersebut tidak terputus hanya sebatas pada pemberian seminar dan ceramah saja. Hasil wawacara dengan para informan terlebiht khusus pihak sekolah, universitas serta masyarakat umum mengharapkan agar materi bela Negara masuk dalam kurikulum dan juga pelaksanaan program bukan hanya sekedar 7 untuk mengejar laporan semata namun harus lebih mengena dan juga meresap serta berkesan dalam pikiran mereka Dalam dunia kemiliteran perubahan kepemimpinan hampir tidak berpengaruh terhadap program TNI apalagi program mengenai kesadaran masyarakat dan bela Negara yang lebih memperkuat pertahanan Negara, semua pemimpin bangsa selalu konsisten dalam upaya mempertahankan kedaulatan dan keberlangsungan bangsa dan Negara. Dalam dunia kemiliteranpun perubahan struktur kepemimpinan ditingkatan paling atas juga tidak merubah apa yang sudah dilakukan, kenyataan terlihat dari undangundang mengenai pertahanan Negara yang sejak 2002 dikeluarkan hingga sampai saat ini tetap dipertahankan dan dijalankan secara konsisten karena menyangkut keberlangsungan bangsa baik sekarang maupun kedepan. Pelaksanaan kegiatan Pembinaan Bela Negara, Kodim 1309/Manado menyelenggarakan Perencanaan, Pengembangan, Pengerahan dan Pengendalian potensi wilayah Pertahanan dengan segenap aspeknya untuk menjadi kekuatan sebagai ruang, alat dan kondisi juang yang tangguh serta mewujudkan Kemanunggalan TNI dengan rakyat untuk kepentingan Pertahanan Aspek Darat. Dalam pelaksanaan fungsi utamanya Kodim 1309/Manado di bantu oleh 5 (lima) Koramil sebagai unsur Pelaksana Kodim. Hasil penelitian ditinjau dari strategi Kelembagaan yang dilakukan Kodim 1309/Manado kepada Koramil jajarannya sudah baik dengan melalui bentuk-bentuk controlling. Disamping itu juga Korem 131/Stg sebagai Satuan Kewilayahan di atas Kodim 1309/Manado memiliki wewenang melaksanakan kegiatan supervisi terhadap setiap kegiatan Bela Negara yang di lakukan oleh Kodim 1309/Manado dan Koramil jajarannya. Hasil penelitian ini juga menunjukan strategi Kelembagaan dalam menerapkan kebijakan-kebijakan terhadap pengembangan Satuan atau Kelembagaan antara lain: a. Pengajuan kekurangan Personel ke Satuan atas dalam hal ini diajukan ke Korem 131/Stg dalam pemenuhan Personel untuk mengefektifkan pelaksanaan tugas. b. Koordinasi dengan 
Forkopimda Kota Manado, Kabupaten Minahasa dan Kabupaten Minahasa Utara serta Dinas terkait untuk pelaksanaan kegiatan Bela Negara. c. Pembinaan Personel melalui kegiatan Pendidikan yang berkaitan dengan Wawasan Kebangsaan dan Bela Negara untuk membekali Personel Kewilayahan dalam memberikan materi Bela Negara. Hasil penelitian menunjukan strategi Kelembagaan dalam menentukan sasaransasaran kebijakan menurut sebagian Informan masih banyak hambatanhambatan dikarenakan terbatasnya Sumber Daya Manusia (SDM) yang melaksanakan controlling terkait mengatasi permasalahan Pembinaan Bela Negara oleh Kodim 1309/Manado dengan hal itu proses kebijakan dalam strategi Kelembagaan harus dilaksanakan secara optimal. Secara umum keberadaan sumber daya bukan hanya berbicara mengenai manusia saja tapi termasuk di dalamnya sarana dan prasarana yang dimiliki sejauh ini masih dianggap cukup memadai jika itu digunakan sebagai modal awal. Dan semua sumber daya itu akan menjadi semakin optimal jika dapat dikelola dengan peruntukan yang tepat. Pada penelitian ini aspek yang dilihat dari 8 sumberdaya ini adalah kuantitas dan kualitas prajurit TNI serta ketersediaan sarana pendukung dalam mengimplementasikan program bela Negara. Dari factor-faktor tersebut merupakan salah satu kelemahan dalam mengimpelemtasikan kebijkan tersebut. Kelemahan yang dimaksud ialah keterbatasan atau kekurangan dalam hal sumber, keterampilan dan kemampuan yang menjadi penghalang serius bagi penampilan kinerja Organisasi yang memuaskan. Kelemahan yang dirasakan oleh Organisasi antara lain lokasi yang jauh dari fasilitas umum, Sumber Daya seperti kondisi keuangan yang tidak stabil, terbatasnya tenaga terampil, kekurangmampuan dalam memanfaatkan Sumber Daya yang ada, kurang disiplin karyawan, pertentangan antar Kelompok dan lemahnya Kepemimpinan.

Salah satu akar dari kelemahan Organisasi ialah apabila Organisasi tidak memiliki tujuan dan sasaran serta struktur Organisasi yang tidak teratur.Seperti telah diuraikan diatas bahwa wilayah binaan Kodim 1309/Manado mencakup wilayah Kota Manado, sebagian Kabupaten Minahasa dan Kabupaten Minahasa Utara. Dari data yang ada menyebutkan bahwa wilayah binaan Kodim 1309/Manado seluas 157,23KM 3 dengan 11 Kecamatan 87 Kelurahan dan 504 Lingkungan/Jaga. Wilayah seluas itu dalam pelaksanaan Pembinaan Bela Negara dilaksanakan oleh 5 (lima) Koramil menjadi salah satu kendala dalam pencapaian Program yang akan dilaksanakan. Dalam penelitian ini disimpulkan bahwa Pembinaan Bela Negara yang dilaksanakan oleh Kodim 1309/Manado dan jajarannya di wilayah Kota Manado, sebagian wilayah Kabupaten Minahasa dan Kabupaten Minahasa Utara belum cukup maksimal jika dihadapkan pada sasaran atau tujuan pelaksanaan kegiatan Bela Negara dengan hasil yang dilaksanakan. Hal tersebut dapat kita lihat dari faktor internal masih terdapatnya kekurangan Personel pelaksana baik di Kodim1309/Manado itu sendiri dan Koramil jajarannya, tingkat pemahaman Anggota terhadap Peraturan yang berkaitan dengan Bela Negara serta ketersediaan Sarana dan Prasarana yang menunjang kegiatan Bela Negara. Dalam implementasi kebijakan di dunia pemerintah, ada fenomena yang menarik seperti kecenderungan umum bahwa perubahan di tingkat kelembagaan atau struktur birokrasi ternyata tidak otomatis (mudah) diikuti dengan perilaku perubahan aparatur birokrasi yang akan menjalankan kebijakan publik.

Namun kecenderungan ini sangat kecil kemungkinan terjadi dalam dunia kemiliteran karean pada hakekatnya didikan bagi prajurit sangat menekankan pada kepatuhan terhadap atasan dan perintah yang diberika bahkan mengorbankan jiwa dan raga mereka untuk menjalankan perintah yang diberikan. Termasuk didalamnya perintah untuk menjalankan program bela Negara kepada masyarakat. Strategi atau program Pembinaan Bela Negara yang dilakukan oleh Kodim 1309/Manado dalam program bela Negara adalah meningkatkan kesadaran Bela Negara bagi setiap Warga Negara di wilayah binaan Kodim 1309/Manado dalam rangka mendukung kepentingan Pertahanan Negara dan Ketahanan Nasional. Hasil penelitian ini menujukan Pembinaan Bela Negara di wilayah Kota Manado sudah sesuai dengan pedoman Pembinaan Bela Negara yang dikeluarkan oleh Pusat Teritorial Angkatan Darat (Pusterad) dalam rencana kegiatan tersebut Kodim 1309/Manado melaksanakan rapat9 rapat untuk membahas program-program yang akan dilaksanakan program jangka pendek maupun jangka panjang, setelah program diputuskan maka hasil program itu akan di realisasikan. Dalam penelitian ini masih ada kecenderungan atau masalah dalam Program terkait mengatasi permasalahan Bela Negara yaitu terbenturnya beberapa kegiatan yang harus dilaksanakan belum lagi ditambah dengan program Satuan atas yang bersifat Protokoler yang dibebankan ke Satuan Pelaksana dalam hal ini Kodim dan Koramil.

Dalam penelitian ini menujukan bahwa Personel Kodim 1309/Manado dan Koramil jajarannya sudah terlibat dalam proses pelaksanaan Pembinaan program terkait mengatasi masalah 
Pembinaan Bela Negara di wilayah Kota Manado, sebagian wilayah Kabupaten Minahasa dan Kabupaten Minahasa Utara. Namun dalam penelitian ini terdapat banyak kelemahan-kelemahan yang di ungkapkan oleh beberapa Informan tentang kinerja yang belum maksimal dikarenakan pelaksanaan Program Bela Negara belum menyentuh ke seluruh lapisan masyarakat

\section{KESIMPULAN}

Hasil penelitian menunjukkan bahwa :

1. Pembinaan Bela Negara yang dilaksanakan oleh Kodim 1309/Manado dan Satuan Komando Kewilayahan (Satkowil) merupakan amanat Undang-Undang yang dibebankan kepada Tentara Nasional Indonesia (TNI) dalam rangka mewujudkan Ketahanan Nasional dan menjadi payung hukum dalam pelaksanaannya, dalam proses komunikasi yang dilakukan oleh pihak Kodim 1309 selaku implementor dilaksanakan dengan membangun komunikasi dengan stakeholder seperti pemerintah daerah, pimpinan sekolah dan universitas yang ada di wilayah kodim 1309 dalam prosesnya berjalan dengan baik dan diterima oleh stakeholder dan masyarakat pada umumnya.

2. Secara struktur birokrasi strategi Kelembagaan yang dilakukan Kodim 1309/Manado kepada Koramil jajarannya sudah baik dengan melalui bentuk-bentuk controlling. Disamping itu juga Korem 131/Stg sebagai Satuan Kewilayahan di atas Kodim 1309/Manado memiliki wewenang melaksanakan kegiatan supervisi terhadap setiap kegiatan Bela Negara yang di lakukan oleh Kodim 1309/Manado dan Koramil jajarannya. Dalam hal struktur birokrasi tertata dengan jelas dengan kesatuan perintah yang dilaksanakan dari atas ke bawah.

3. Pada aspek sumberdaya dalam rangka mengimplementasikan kebijakan bela Negara, yang digunakan kodim 1309 berupa sumberdaya manusia yakni personel prajurit dan sarana yang tersedia. namun kegiatan tersebut belum maksimal karena terdapat kelemahan seperti belum terpenuhinya jumlah Personel yang ideal untuk melaksanakan kegiatan Bela Negara dihadapkan dengan berbagai kegiatan yang harus dilaksanakan. Selain itu kualitas personel yang tidak merata, masih ada beberapa yang belum paham mengenai konsep bela Negara dan pelaksanaannya.

4. Sikap pelaksana kebijakan dalam hal ini prajurit yang ada di Kodim 1309, dari hasil penelitian belum menunjukkan memberikan hasil yang 10 maksimal dari yang diharapkan, dimana kegiatan bela Negara yang belum berjalan secara berkelanjutan menjadi halangan bagi efektivitas program bela Negara yang telah dilakukan.

\section{DAFTAR PUSTAKA}

Herdiansah, A. G., Ummah, K. C., \& Simanjuntak, S. 2017. Peran dan Fungsi Pembinaan Teritorial TNI AD dalam Perbantuan Pemerintah Daerah: Studi di Kabupaten Lebak. CosmoGov: Jurnal Ilmu Pemerintahan, 3(1), 65-82.

Mabes AD. 2016. Buku Petunjuk Teknis Pembinaan Teritorial

Edwards III dan G. C. 1980. Implementing Public Policy. Washington : Congressional Quarterly Press.

Kompasiana.Com.2009. Ketahanan Nasional Bergantung Pada Hubungan Sipil- Militer.

Makalassa, S. 2005. Memahami Administrasi dalam Teori Optimalisasi Organisasi. PT. Grafindo Persada, Jakarta.

Saefullah D. H. A. 2007. Pemikiran Kontemporer Adminsistrasi Publik, Perspektif Manajemen Sumber Daya Manusia Dalam Era Desentralisasi. Cetakan kedua. Bandung : LP3AN FISIP UNPAD.

Samego I. 2001. Sistem Pertahanan-Keamanan Negara: Analisis Potensi \& Problem. Jakarta: The Habibie Center

Tachjan. 2008. Implementasi Kebijakan Publik. Bandung : AIPI Bandung.

Tap MPR RI No. VI/MPR/2000, Tap MPR RI No. VII/MPR/2000, tentang Pemisahan TNI dan Polri

Tjandrawati, Abdul Rahman Kadir, Syamsu Alam 2010. Manajemen Pemberdayaan Aparat Teritorial Dalam Mendukung Sistem Pertahanan Rakyat Semesta Program Master pada Universitas Hasanuddin. Sumber: http://pasca.unhas.ac.id/ jurnal/files/6a917001 e13f431d4fcbc5e060746c96.pdf

Undang-undang RI Nomor 34 Tahun 2004 tentang Tentara Nasional Indonesia (TNI)

Undang-undang RI Nomor 3 Tahun 2002 tentang Pertahanan Negara

Wahab, Solichin Abdul. 2001. Analisis Kebijaksanaan dari Formulasi ke Implementasi Kebijakan Negara. Jakarta: Bumi Aksara.

Wibowo R. 2015. Pembinaan Teritorial Desa Di Kecamatan Balai Jaya Kabupaten Rokan Hilir Tahun 2015. Jurnal Jurusan Ilmu Pemerintahan Fakultas Ilmu Sosial Dan Ilmu Politik Universitas Riau. 